Dragonflies are essentially tropical insects and none of those present in Britain are endemic, so why should we be concerned that some of our few species have become extinct? The answer is simply that many dragonfly species, including all those that have become extinct in Britain, are quite local in their total distribution, and they are all under threat in other parts of their range as well. ${ }^{1}$ Therefore, unless every country attempts to conserve its own species they are likely to become greatly reduced in the world as a whole, and some will become totally extinct. What is happening to dragonflies should act as a warning to those concerned with the conservation of other aquatic animals which are less well known.

\section{References}

1. DUMONT, H.J. 1971. Need for protection of some European dragonflies. Biol. Cons. 3: 223-228.

2. MOORE, N.W. 1976. The conservation of Odonata in Great Britain. Odonatologica 5: 38-44.

3. MOORE, N.W. 1980. Lestes dryas Kirby - a declining species of dragonfly (Odonata) in need of conservation: notes on its status and habitat in England and Ireland. Biol. Cons. 17: 143-148.

Professor Norman Moore, The Nature Conservancy Council, 19/20 Belgrave Square, London SW1P 8PY.

\title{
Newly Protected Plants in Britain
}

\section{Richard Fitter}

The new Wildlife and Countryside Act has protected 42 more wild plants throughout Britain, in addition to 20 of the 21 described in Oryx, May 1981. The one omitted, mezereon Daphne mezereum, is now considered to be out of danger - I know of three or four sites in the Chilterns alone.

Of the new species only one is a fern, Cystopteris dickieana, which grows in one or two sea caves in the east coast of Scotland. There are also two shrubs, the Plymouth pear Pyrus cordata, confined to a few hedges round Plymouth, and wild cotoneaster Cotoneaster integerrimus, a speciality of the limestone headland of the Great Orme behind Llandudno. Four orchids form the largest group of the remaining 39 plants, to add to the five already protected: both the early and late spider orchids Ophrys sphegodes and $O$. fuciflora, confined to chalk turf from Kent to Dorset and in East Kent respectively; the fen orchid Liparis loeselii, rare in East Anglia and South Wales; and the lizard orchid
Himantoglossum hircinum, a speciality of the Kentish dunes which unexpectedly appeared recently on a nature reserve only a mile or two outside a city boundary in the centre of England. There are also two members of the Lily Family, round-headed leek Allium sphaerocephalon, confined to the limestone rocks of the Avon Gorge at Bristol, and whorled Solomon's seal Polygonatum verticillatum, in the north, mainly in Perthshire, as well as one member of the Iris Family, the wild gladiolus Gladiolus illyricus, which still grows under bracken in the New Forest in those few spots where the gipsies cannot find it to sell in the local markets.

Two more groups are three broomrapes and three sedges. The broomrapes, those extraordinary parasites which lack green chlorophyll and suck their nutriment from other plants' roots, are the bedstraw and oxtongue broomrapes Orobanche caryophyllacea and $O$. loricata, both on the named host plants in East Kent, and thistle broom- 
rape $O$. reticulata, which is too rare in Yorkshire to represent any threat to the innumerable thistles of that broad county - indeed one wonders why the parasite of such a common group of plants should be so rare. The three sedges are brown galingale Cyperus fuscus, which appears irregularly around muddy ponds in the south, starved wood-sedge Carex depauperata, which may still be hanging on not far from the World Wildlife Fund's new headquarters at Godalming, Surrey, and triangular club-rush Scirpus triquetrus, confined to the Tamar and one or two other muddy southern estuaries.

Of the remainder, the most notable are: adderstongue spearwort Ranunculus ophioglossifolius, a rare buttercup with only two sites, both in Gloucestershire, one of which qualifies as the smallest nature reserve for the Guinness Book of Records; alpine catchfly Lychnis alpina, with only two sites, one in the Lake District and the other on the high moors at the head of Glen Clova, Angus; field wormwood Artemisia campestris, one of the specialities of the East Anglian Breckland, around Thetford; downy wound- wort Stachys germanica, which appears in most years on the limestone north of Oxford; least lettuce Lactuca saligna, with only one good colony, on a sea wall in Essex; and wood calamint Calamintha sylvatica, which for many years, since at least 29 August 1843 to be precise, has adorned a single bank in the Isle of Wight.

It is an offence to pick, uproot, destroy or sell any of the 62 plants now protected by the new Act, or even to attempt to do any of these things. It also remains an offence to uproot any plant without the permission of the landowner or occupier. To qualify for the new schedule a wild plant must be "in danger of extinction or likely to become so unless conservation measures are taken'. This means that vulnerable as well as actually endangered plants can now be protected. And it is the duty of the Nature Conservancy Council to review the schedules at five-year intervals and recommend additions and subtractions. So for the first time Great Britain has a reasonably comprehensive measure for protecting rare plants.

\section{Sperm Whales' Fate Postponed Again}

\section{Richard Fitter}

At its annual meeting last July the International Whaling Commission deferred a decision on the sperm whale quota for the North Pacific to a special meeting in March this year in Brighton. This proved the most inconclusive meeting the IWC has ever held. Once more the decision was postponed, this time until next July. Seven days of deliberation by the Scientific Committee in Cambridge three weeks previously had produced, as so often before thanks to inadequate data and disputed computer models, an ambiguous choice of options. The IWC commissioners had to choose between a quota of 890 male sperm whales, a nil quota, or putting it off again. They put it off again. The reasons for the scientific ambiguity are exceedingly complex, but there is no reason to suppose that they will be any less complex next July or that the recommendations will be any different. But it is always easier to do nothing than to do something. One may well wonder whether all this expenditure of scarce resources, scientific as well as financial, is justified. Technically the allocation of a quota would infringe the IWC's New Management Procedure (NMP), but in practice the quota of 890 would make little difference to the rate of species 